\title{
PERAN IBU DALAM MENUMBUHKAN JIWA WIRAUSAHA ANAK
}

\author{
Oleh \\ Sukanti ${ }^{1}$ \\ Aliyah Rasyid Baswedan ${ }^{2}$ \\ Isroah $^{3}$
}

\begin{abstract}
Abstraks
Penelitian ini bertujuan untuk mengetahui: (1) peran pendidikan dalam keluarga dalam menumbuhkembangkan jiwa wirausaha anak, (2) peran ibu dalam menumbuhkan dan mengembangkan jiwa wirausaha pada anak, dan (3) faktor-faktor yang dominan untuk berkembangnya jiwa wirausaha.

Penelitian ini menggunakan penelitian kualitatif. Pendekatan ini dianggap paling sesuai karena dapat mengungkap permasalahan wirausaha, khususnya untuk mengungkap peran keluarga lebih khusus lagi ibu dalam mengembangkan jiwa wirausaha anak dan ibu yang telah melahirkan wirausaha-wirausaha yang sukses. Direncanakan subjek dalam penelitian ini adalah ibu yang mempunyai anak yang sukses sebagai wirausaha yang berdomisili di Yogyakarta, yang berjumlah 8 orang. Setting penelitian yang dianggap tepat bagi penelitian ini adalah di tempat responden berada baik di tempat kegiatan maupun di rumah responden. Pengumpulan data dilakukan dengan teknik wawancara secara mendalam (in-depth interview). Wawancara secara mendalam digunakan untuk mengungkap latar belakang kehidupan. Selain dengan wawancara juga digunakan observasi. Dalam penelitian kualitatif peneliti bertindak sebagai instrumen (human instrument). Analisis data dilakukan baik ketika masih dalam tahap pengumpulan data maupun setelah data terkumpul seluruhnya dengan teknik deskriptif. Teknik untuk mencapai kredibilitas penelitian dengan trianggulasi teknik dan sumber.

Hasil penelitian menunjukkan: (1) Secara umum pendidikan dalam keluarga berperan dalam menumbuhkan jiwa wirausaha anak. Wirausaha yang sukses pada umumnya dipicu dengan pendidikan yang demokratis, melatih kemandirian, kepercayaan diri dan kerja sama, disiplin, serta menghargai orang lain. (2) Kebanyakan (75\%) ibu berperan dalam menumbuhkankan jiwa wirausaha pada anak, ajakan Ibu untuk melibatkan anak dalam kegiatan kewirausahaan menjadikan anak untuk mempertimbangkan wirausaha sebagai pilihan karirnya (3) Faktor-faktor yang dominan untuk berkembangnya jiwa wirausaha adalah lingkungan/ personal environmental yaitu pengaruh dari luar. Sebagian reponden $(87,5 \%)$ yang sukses berwirausaha karena orang tuanya berkecimpung di bidang kewirausahaan.
\end{abstract}

Kata Kunci : Ibu, Pendidikan, Kewirausahaan

\section{A. Pendahuluan}

Selama 32 (Tiga puluh dua) tahun silam ekonomi Indonesia mengalami pertumbuhan yang tinggi (7-8\%), inflasi di bawah 10\%, investasi luar negeri meningkat, cadangan devisa cukup besar serta menurunnya angka kemiskinan. Krisis ekonomi yang terjadi semakin parah yang akhirnya melebar sehingga menimbulkan terjadinya krisis

\footnotetext{
${ }^{1}$ Dosen Jurusan Pendidikan Akuntansi - Universitas Negeri Yogyakarta

${ }^{2}$ Dosen Jurusan Pendidikan Akuntansi - Universitas Negeri Yogyakarta

${ }^{3}$ Dosen Jurusan Pendidikan Akuntansi - Universitas Negeri Yogyakarta
} 
kepercayaan, baik pada lembaga-lembaga ekonomi, seperti perbankan maupun pemerintah. Perekonomian Indonesia yang saat ini masih belum membaik, sehingga telah mengakibatkan banyak industri yang menghentikan proses produksinya, yang kadang mengakibatkan terjadinya pemutusan hubungan kerja (PHK), yang dampak selanjutnya mengakibatkan tingginya tingkat pengangguran. Peningkatan pengangguran mengakibatkan makin maraknya tindak kejahatan, kriminalitas pelanggaran norma dan kesusilaan sehingga akan mengganggu stabilitas ekonomi, politik, keamanan maupun ketenteraman masyarakat pada umumnya.

Berdasarkan permasalahan tersebut, perlu segera dilakukan upaya khususnya yang berkaitan dengan perluasan kesempatan kerja dan kesempatan berusaha. Untuk itu salah satu usaha yang dapat dilakukan adalah perlu ditumbuhkembangkan budaya kewirausahaan di seluruh lapisan masyarakat.

Pemasyarakatan dan pembudayaan kewirausahaan ini sangat penting mengingat kenyataan bahwa pertumbuhan dan perkembangan pengusaha-pengusaha Indonesia atas dasar kewirausahaan bersifat turun temurun dan bukan melalui pendidikan formal. Selain itu hanya sekitar $2 \%$ pengusaha Indonesia yang berpendidikan Diploma atau politeknik dan sebagian besar adalah lulusan Sekolah Dasar (SD). Berbagai kebijakan maupun kerja sama antar departemen perlu dilakukan agar mengembangkan jiwa wirausaha maupun kegiatan yang produktif.

Kebanyakan orang tua kurang memberi arahan kepada anaknya agar mempunyai jiwa wirausaha atau berwirausaha. Sejak kecil banyak orang tua lebih mengarahkan anaknya untuk memiliki cita-cita semacam dokter, guru, insinyur dan pekerjaan formal lainnya. Walaupun untuk profesi-profesi inipun jiwa entrepreneur sangat diperlukan dan sangat membantu untuk keberhasilannya.

Sebenarnya kita ditakdirkan berbekal kewirausahaan. Semua manusia dibekali sifat-sifat kewirausahaan sejak lahir. Sejak lahir sudah dibekali keberanian, kreativitas dan inisiatif. Anak belajar berjalan tanpa harus masuk di kelas. Setiap kali tersandung ia bangkit lagi. Ia belajar bicara dengan penuh ketekunan, ia belajar dari sekelilingnya. Namun setelah tumbuh tidak semua anak dibekali dengan prinsip-prinsip hidup positif, dinamis dan kreatif, padahal posisi dan peran keluarga khususnya ibu sebagai pendidik awal yang meletakkan pondasi terpenting bagi pertumbuhan personalitas serta kematangan berpikir anak.

Oleh karena pendidikan dalam keluarga kurang berperan secara optimal, akibatnya pertumbuhan kepribadian, kepercayaan diri ataupun keyakinan hidup anak tidak tumbuh optimal dan stabil. Tanpa bekal iman dan kepribadian dari rumah yang mantap, anak-anak akan mudah digoncang oleh pengaruh lingkungan. Mereka mudah terombang ambing karena memang belum memiliki prinsip hidup yang mantap sehingga pendidikan dalam keluarga, khususnya ibu sangat berperan dalam menumbuhkan pribadi-pribadi unggul yang sangat diperlukan untuk kemajuan suatu masyarakat, bangsa dan negara. Jiwa unggul inilah yang diperlukan dalam entrepreneurship.

Wirausaha atau entrepreneurship ini tidak hanya diperlukan untuk berbisnis saja, hampir dalam segala bidang sangat dibutuhkan jiwa entrepreneur untuk keberhasilan kerja dan keberhasilan organisasi apapun. Karena semangat kerja, kreativitas, disiplin, inovatif, gigih, kerja tidak mudah putus asa merupakan karakteristik jiwa unggul yang diperlukan di bidang apa saja.

Dalam upaya tumbuhnya karakteristik jiwa unggul secara khusus jiwa entrepreneur sangat ditentukan oleh pendidikan sejak dini yang akan merupakan landasan yang kokoh dan kuat. Pendidikan dini ini dilakukan dalam keluarga dan peran ibu sangat dominan dan sangat menentukan.

Berdasarkan latar belakang masalah tersebut di atas dalam penelitian ini ingin 
diketahui peran pendidikan dalam keluarga khususnya peran ibu dalam menumbuhkan jiwa wirausaha seorang anak.Permasalahan yang akan diteliti antara lain:

1. Bagaimanakah peran pendidikan dalam keluarga dapat menumbuhkan jiwa wirausaha anak?

2. Bagaimanakah peran ibu dalam menumbuhkan jiwa wirausaha anak?

3. Faktor-faktor apa yang dominan untuk berkembangnya jiwa wirausaha anak?

Berdasarkan rumusan masalah yang telah dikemukakan di atas, maka tujuan penelitian ini untuk mengetahui :

1. Peran pendidikan dalam keluarga dalam menumbuhkan jiwa wirausaha anak.

2. Peran ibu dalam menumbuhkan jiwa wirausaha anak.

3. Faktor-faktor yang dominan untuk berkembangnya jiwa wirausaha anak.

\section{Keluarga}

Keluarga adalah merupakan lembaga pendidikan yang pertama dan utama dalam masyarakat karena dalam keluargalah anak dilahirkan dan berkembang menjadi dewasa. Bentuk dan isi serta cara-cara pendidikan dalam keluarga akan selalu mempengaruhi tumbuh dan berkembangnya watak, budi pekerti dan kepribadian tiap-tiap manusia. Jadi keluarga merupakan kelompok sosial pertama dan utama dalam kehidupan anak, dimana anak akan belajar tumbuh dan berkembang. Pendidikan dalam keluarga ini merupakan fondasi yang kokoh untuk kehidupan anak di masa depannya. Disinilah tata nilai, pembiasaan, pelatihan disemaikan dan dikembangkan.

Fungsi lembaga pendidikan dalam keluarga yaitu:

a. Merupakan pengalaman pertama di masa kanak-kanak, pengalaman ini merupakan faktor yang sangat penting bagi perkembangan berikutnya, khususnya dalam perkembangan pribadinya.

b. Pendidikan di lingkungan keluarga dapat menjamin kehidupan emosional anak untuk tumbuh dan berkembang. Kehidupan emosional ini sangat penting dalam pembentukan pribadi anak.

c. Di dalam keluarga akan terbentuk pendidikan moral. Keteladanan orang tua dalam bertutur kata dan berperilaku sehari-hari akan menjadi wahana pendidikan moral bagi anak di dalam keluarga, guna membentuk manusia susila.

d. Di dalam keluarga akan tumbuh sikap tolong menolong, tenggang rasa sehingga tumbuhlah kehidupan keluarga yang damai dan sejahtera. Setiap anggota keluarga memiliki sikap sosial yang mulia, dengan cara yang demikian keluarga akan menjadi wahana pembentukan manusia sebagai makhluk sosial

e. Keluarga merupakan lembaga yang memang berperan dalam meletakkan dasardasar pendidikan agama. Kebiasaan orang tua membawa anaknya ke masjid merupakan langkah yang bijaksana dari keluarga dalam upaya pembentukan anak sebagai makhluk religius.

Menurut Slameto (2010 : 15) faktor-faktor yang mempengaruhi keberhasilan anak dalam mencapai keberhasilan dibedakan menjadi enam yaitu

a. Cara orang tua mendidik. Cara orang tua mendidik anaknya besar pengaruhnya terhadap belajar anaknya. Keluarga yang sehat, besar artinya untuk pendidikan dalam ukuran kecil, tetapi bersifat menentukan untuk pendidikan dalam ukuran besar yaitu pendidikan bangsa, negara dan dunia.

b. Relasi antar anggota keluarga. Relasi antar anggota keluarga yang terpenting adalah relasi orang tua dengan anaknya. Selain itu relasi anak dengan saudaranya atau dengan anggota keluarga. Demi kelancaran belajar serta keberhasilan anak, perlu diusahakan relasi yang baik di dalam keluarga anak tersebut. 
c. Suasana rumah. Situasi rumah dimaksudkan sebagai situasi atau kejadian-kejadian yang sering terjadi di dalam keluarga dimana anak berada dan belajar.

d. Keadaan ekonomi keluarga. Keadaan ekonomi keluarga erat hubungannya dengan belajar anak. Anak yang sedang belajar selain harus terpenuhi kebutuhan pokoknya, misal makan, pakaian, perlindungan kesehatan dan lain-lain, juga membutuhkan fasilitas belajar.

e. Pengertian orang tua. Anak perlu dorongan dan pengertian orang tua

f. Latar belakang kebudayaan. Tingkat pendidikan atau kebiasaan di dalam keluarga mempengaruhi sikap anak dalam belajar. Perlu ditanamkan kepada anak kebiasaankebiasaan yang baik, sehingga mendorong anak agar semangat untuk belajar.

Pendidikan entrepreneurship dalam lingkungan keluarga diawali dengan pemberian contoh-contoh yang positif dari orang tua serta pembentukanpembentukan pembiasaan dalam entrepreneurship. Suasana rumah juga sangat berpengaruh terhadap perkembangan dan perilaku anak.

Salah satu faktor yang berperan besar pada pendidikan dalam keluarga adalah ibu. Ibulah yang paling banyak berperan dalam kehidupan awal seorang anak. Ibulah biasanya yang paling dekat dengan kehidupan anak terutama di masa-masa anak masih kecil. Ibu yang lebih banyak menanamkan nilai-nilai positif atau negatif dalam kehidupan anak. Banyak contoh menunjukkan keberhasilan anusiamanusia sukses sangat ditunjang oleh peran ibu dalam mendidiknya. beberapa tokoh terkenal mengemukakan bahwa keberhasilan dirinya sangat ditunjang oleh dukungan cara-cara mendidik, pola asuh dan sikap bijak ibunya dalam mendidik dirinya, terutama ketika belum dewasa. Jadi peran ibu sangat menentukan perannya dalam menciptakan pribadi-pribadi unggul yang sangat diperlukan untuk kemajuan seseorang, kemajuan masyarakat dan kemajuan suatu bangsa.

\section{Entrepreneurship}

Istilah entrepreneurship sering diterjemahkan menjadi kewirausahaan, sehingga penggunaan istilah ini sering dipertukarkan. Wirausaha adalah orang yang mempunyai kreativitas, optimisme, keberanian dan mampu membaca peluang. Dengan demikian wirausaha adalah orang yang berkembang dan mengembangkan setiap potensi dan kemampuan yang dimilikinya.

Hisrich and Peter (1998:9) menjelaskan pengertian entepreneurship sebagai berikut :

"Entrepreneurship is the process of creating new with value with devoting the necessary time and effort, assuming the accompanying financial, physic and social risks, and receiving the resulting rewards of monetary and personal satisfaction and independence".

Hisrich menyatakan kewirausahaan merupakan proses mengkreasi sesuatu yang baru, yang bernilai dengan mencurahkan waktu dan upaya, serta menanggung risiko sehingga dapat mencapai keberhasilan. Zimmerer (2005:5) mendefinisikan entrepreneurship sebagai berikut "An entrepreneurship is one who creartes a new business in the face of risk and uncertainly for the purpose of achieving profit growt, identifying opportunities and assembling the necessary resources to capitalize on those opportunities".

Menurut Zimmerer (2005), kewirausahaan dapat diartikan orang yang menciptakan bisnis baru dengan mengambil risiko dan ketidakpastian demi mencapai keuntungan dan pertumbuhan dengan cara mengidentifikasi peluang dan menggabungkan sumber daya yang diperlukan untuk mendirikannya. Dengan demikian terdapat persamaan persepsi dari ketiga penulis bahwa entrepreneur 
memanfaatkan peluang dan memperhitungkan setiap risiko yang mungkin dihadapi.

Pendapat lain disampaikan oleh Suryana (2005:6) yang mendefinisikan kewirausahaan sebagai kemampuan kreatif dan inovatif dalam menciptakan sesuatu yang baru dan berbeda dan dijadikan dasar, kiat dalam usaha atau perbaikan hidup. Dengan demikian hakikat kewirausahaan adalah kreativitas dan inovasi. Sejalan dengan pendapat tersebut, Husaini Usman (1998:3) menguraikan wirausaha berarti inovator dan creator yang berani mengambil risiko dan memperhatikan peluangpeluang yang ada.

Sedangkan Oenstenk (2003:74) menyatakan bahwa entrepreneurship dilihat sebagai sumber inovasi dan fleksibilitas, sebagai pencipta pekerjaan untuk perekonomian dan pada waktu yang sama sebagai suatu kemungkinan menarik untuk perkembangan individu dan pemenuhan warga negara.

Dari ketiga penulis diketahui bahwa titik kesamaan persepsi tentang kewirausahaan adalah kreativitas dan inovasi. Kreativitas oleh Zimmerer (2005: 40 42) didefinisikan "creativity is the ability to develop new ideas and to discover new ways of looking at problems and opportunity". Kemampuan untuk mengembangkan gagasan-gagasan baru dan untuk menemukan cara-cara baru dalam memecahkan masalah dan menghadapi peluang. Creator berasal dari kata creativity (Wool Folk and Nicolich, 1984), yang berarti "an individual's capacity to produce original or novel product or solution to problems". Jadi Creator adalah orang yang mempunyai kecakapan membuat sesuatu yang baru maupun asli, menyodorkan pemecahan masalah baru sehingga wirausahawan harus berani mengambil risiko. Berdasarkan uraian di atas, ada kesamaan pemikiran tentang arti kreativitas, yaitu berfikir tentang sesuatu yang baru dalam mengatasi masalah.

Dengan kompleksnya deskripsi mengenai entrepreneurships, untuk menjadi entrepreneur sejati diperlukan beberapa hal untuk menunjang keberhasilan dalam usahanya. Lambing dan Kuehl (2003: 23 - 28) menyatakan bahwa individu sebagai wirausahawan harus memiliki tiga belas sifat, yakni : (1) Semangat yang tinggi; (2) Gigih walaupun kadang gagal; (3) Percaya diri; (4) Keteguhan hati; (5) Mampu mengelola risiko; (6) Perubahan dianggap sebagai peluang; (7) Toleransi terhadap ambisi; (8) Berinisiatif dan selalu ingin berprestasi; (9) Orientatif dan kepastian yang mendalam; (10) memanfaatkan waktu luang; (11) Kreatif; (12) Memiliki gambaran global serta kepastian yang mendalam; (13) Motivasi yang tinggi.

Pendapat lain dikemukakan oleh Wasty Sumanto (1989: 45 - 77) bahwa entrepreneure mempunyai ciri : (1) Memiliki moral yang tinggi, yaitu manusia yang bertaqwa kepada Tuhan Yang Maha Esa, memiliki kemerdekaan batin, mementingkan keutamaan, memiliki kasih sayang, loyal terhadap hukum dan memiliki sifat keadilan, (2) Sikap mental wirausahawan yakni berkemauan keras, berkeyakinan kuat atas kekuatan yang ada pada dirinya, jujur dan bertanggung jawab, memiliki ketahanan fisik dan mental, tekun serta ulet dalam bekerja dan berusaha, serta memiliki pemikiran yang konstruktif kreatif, (3) Peka terhadap lingkungan yang meliputi pengenalan terhadap arti lingkungan, senantiasa bersyukur atas segala yang diperoleh dan dimiliki, keinginan yang besar untuk menggali dan mendayagunakan sumbersumber ekonomi di lingkungan setempat, serta menghargai dan memanfaatkan waktu secara efektif, (4) Memiliki keterampilan wiraswasta yang meliputi keterampilan berpikir kreatif, keterampilan membuat keputusan, keterampilan dalam kepemimpinan, keterampilan manajerial serta keterampilan dalam human relations.

Ciri-ciri wirausahawan menurut Husaini Usman (1998: 62 - 63) : (1) Terampil teknik, (2) Terampil sosial, (3) Terampil konseptual, (4) Terampil manajerial, (5) Motif pencapaian tujuan yang kuat, (6) Visi jauh ke depan, (7) innovator, (8) Creator, 
(9) Adaptor, (10) Pekerja keras, (11) Sistematis, (12) Bertanggung jawab, (13) Berdisiplin tinggi, (14) Percaya diri yang kuat, (15) Pelayanan yang memuaskan segala pihak, (16) Berani dengan penuh perhitungan, (17) Belajar dari kesalahan, (18) Kemampuan untuk berunding dengan prinsip saling menguntungkan, (19) Memiliki kepekaan yang tajam terhadap peluang, (20) Latar belakang keluarga, (21) Latar belakang pribadi.

Suryana (2005: 4) mengungkapkan bahwa wirausahawan yang sukses adalah mereka yang memiliki kompetensi dalam hal ilmu pengetahuan, keterampilan dan kualitas individu yang meliputi sikap, motivasi, nilai serta tingkah laku yang diperlukan untuk melaksanakan kegiatan. Keterampilan yang dimaksud adalah keterampilan manajerial (managerial skill), keterampilan konseptual (conceptual skill) dan keterampilan memahami, mengerti, komunikasi dan berelasi (human skill) dan keterampilan merumuskan masalah dan mengambil keputusan (decision making skill), keterampilan mengatur dan menggunakan waktu (time management skill) dan keterampilan teknik lainnya secara spesifik. Semua keterampilan itu harus didukung dengan sikap positif, motivasi dan selalu komit terhadap pekerjaan yang sedang dikerjakannya. Pendapat Suryana ini relevan dengan pendapat Oenstenk.

\section{Faktor-faktor yang menjadi pemicu untuk terjun ke dunia bisnis.}

Menurut Buchari Alma (2005) banyak faktor yang memicu atau memaksa seseorang untuk terjun ke dunia bisnis antara lain:faktor personal, lingkungan dan sosiologis. Faktor personal yang memaksa seseorang terjun ke dunia bisnis adalah:
a. Adanya ketidakpuasan terhadap pekerjaan yang sekarang
b. Adanya pemutusan hubungan kerja (PHK), dan tidak ada pekerjaan lain
c. Dorongan karena faktor usia
d. Keberanian menanggung risiko
e. Komitmen atau minat yang tinggi terhadap bisnis

Apakah sebenarnya yang paling mendorong seseorang untuk memasuki karir wirausaha? Jawabannya menyangkut dua hal yaitu: personal atributes dan personal environment. Menurut David Mc Clelland dalam Buchari Alma (2005) menyatakan bahwa seorang wirausaha adalah seorang yang memiliki keinginan berprestasi yang sangat tinggi dibandingkan dengan orang lain. Dalam suatu penelitian di Inggris bahwa motivasi seseorang membuka bisnis adalah 50\% ingin mempunyai kebebasan dengan berbisnis sendiri, hanya $18 \%$ menyatakan ingin memperoleh uang dan $10 \%$ menyatakan membuka bisnis untuk kesenangan, hobi, tantangan, atau kepuasan pribadi dan melakukan kreativitas. Faktor personal environmental yaitu pengaruh dari luar. Di Indonesia ada beberapa daerah atau lokasi yang banyak wirausahanya. Suasana semacam ini sangat berpengaruh kepada warga masyarakat untuk menumbuhkan minat berwirausaha.

\section{B. Metode Penelitian}

Penelitian ini menggunakan penelitian kualitatif. Pendekatan ini dianggap paling sesuai karena dapat mengungkap permasalahan entrepreneurship, khususnya untuk mengungkap peran keluarga lebih khusus lagi ibu dalam mengembangkan jiwa entrepreneurship anak dan ibu yang telah melahirkan entrepreneur-entrepreneur yang sukses. Metode penelitian ini meliputi penentuan subjek penelitian, pemilihan setting penelitian, teknik pengumpulan data, teknik analisis data, dan teknik untuk mencapai kredibilitas penelitian.

Subjek penelitian ini ditentukan dengan kriteria seleksi berdasarkan tujuan tertentu, atau dikatakan purposive sampling dan snow ball sampling. Responden adalah 
keluarga dan ibu yang mempunyai anak sebagai entrepreneur sukses di Yogyakarta. Subjek penelitian meliputi keluarga dan ibu yang jumlahnya terbatas, agar memungkinkan peneliti mengumpulkan data kualitatif yang memadai. Direncanakan subjek penelitian adalah keluarga dan ibu yang mempunyai anak sebagai wirausaha sukses, tetapi karena keterbatasan dalam penelitian ini maka yang menjadi responden adalah wirausaha yang berjumlah 8 responden.

Setting dianggap tepat bagi penelitian ini di tempat responden berada baik di tempat kegiatan maupun di rumah responden. Tempat kegiatan yang sesuai untuk mengamati berbagai hal yang terkait dengan kegiatan subyek. Sedang rumah responden merupakan tempat yang sesuai untuk mengungkap data lewat wawancara mendalam. Namun apabila subjek penelitian menghendaki agar wawancara dilakukan di tempat tertentu juga akan disesuaikan, seperti di tempat kerja, dan lain-lain.

Pengumpulan data dilakukan dengan teknik wawancara secara mendalam (indepth interview). Wawancara secara mendalam digunakan untuk mengungkap latar belakang kehidupan. Dalam penelitian kualitatif peneliti bertindak sebagai instrumen (human instrument). Hal ini memungkinkan peneliti memodifikasi pertanyaan sesuai dengan kondisi subjek penelitian. Wawancara didasarkan pada beberapa pertanyaan focus yang sudah peneliti siapkan, tetapi masih dimungkinkan diadakan pengembangan disesuaikan dengan kebutuhan untuk mengungkap berbagai dimensi yang terkait dengan fenomena glass-ceiling tanpa mengabaikan kondisi personal subjek penelitian.

Analisis data dilakukan ketika masih dalam tahap pengumpulan data maupun setelah data terkumpul seluruhnya. Pada tahap pengumpulan data, dilakukan pengkodean terbuka bagi data yang telah terkumpul, maksudnya, semua kategori yang muncul dicatat. Kemudian pada pertengahan pengumpulan data, dilakukan pengkodean aksial atau berporos, yakni dipilih kategori yang nanti akan menjadi kategori inti. Akhirnya menjelang akhir pengumpulan data dan setelah data terkumpul seluruhnya, dilakukan pengkodean selektif yakni dipusatkan pada kategori inti yang nanti akan menjadi tematema penting yang ditulis dalam laporan penelitian.

Pengkodean (pengkategorian) akan dilakukan berdasarkan kondisi, interaksi, strategi dan konsekuensi (Strauss, 1987 : 27-28). Penemuan kategori kondisi dilakukan berdasarkan pernyataan-pernyataan subjek mengenai proses pendidikan dan pembiasaan dan lingkungan anak. Kata-kata yang secara eksplisit menandai adanya kategori khusus "kondisi" seperti sebab, sejak, atau sementara, yang muncul pada data hasil wawancara secara mendalam dan pada catatan lapangan (field notes) dimanfaatkan untuk menemukan kategori "kondisi". Selanjutnya kategori "interaksi" ditemukan dari interaksi yang terjadi antara subjek penelitian dengan pihak-pihak lain yang terkait dengan entrepreneurship. Demikian juga interaksi antara subjek penelitian dengan anggota keluarga. Kategori "strategi" dapat diketahui dari taktik-taktik khusus yang dilakukan oleh subjek penelitian untuk mengatasi masalah yang menghambat maupun yang menjadi kendala dalam mendidik dan membiasakan anak. Tahap terakhir adalah kategori "konsekuensi" dapat diketahui dari frase-frase : sebagai akibatnya, karena itu, akibatnya yaitu, konsekuensinya adalah, dan disebabkan oleh. Analisis berikutnya ini menggunakan pola "konsep indikator" (Strauss, 1987:25) sehingga ditemukan konsep-konsep penting mengenai pendidikan dalam keluarga khususnya yang dilakukan ibu.

Kredibilitas penelitian ini akan dicapai dengan :

1. Trianggulasi, yang berwujud penggunaan teknik pengumpul data ganda yaitu pengamatan berpartisipasi dan wawancara secara mendalam untuk mengecek keabsahan data

2. Tanya jawab dengan teman sejawat (peer briefing) guna mengecek kebenaran penafsiran data oleh peneliti. 


\section{Hasil Penelitian dan Pembahasan \\ 1. Peran Pendidikan dalam Keluarga dapat Menumbuhkan Jiwa Entrepreneurship Anak.}

Ibu Hy usaha di bidang konveksi, beliau tinggal di Klaten. Setelah kuliah (kira-kira berusia 22 tahun) terjadilah perubahan besar pada diri Ibu Hy yang semula tidak berani mengambil risiko menjadi sangat berani, namun beliau tidak bersedia memberikan penjelasan mengapa bisa berubah 180 derajat dari tidak berani mengambil risiko menjadi sangat berani, beliau hanya menyatakan bahwa orang yang berani mengambil risiko, ketika ada masalah akan siap menghadapinya. Berhubungan dengan masalah yang sering dihadapi Ibu Hy, beliau berprinsip setiap permasalahan pasti ada jalan keluar, Ibu Hy optimis dapat mengatasinya. Setelah Ibu Hy memperlihatkan hasil dari keberanian mengambil risiko maka orang tua Ibu Hy mendukung $100 \%$. Orang tua melatih kemandirian sejak kuliah di Yogyakarta karena sebelumnya lebih banyak tergantung pada orang tua. Kemandirian inilah yang dapat mendorong menjadi wirausaha.

Bapak Xa merupakan anak pertama dan memiki adik laki-laki, orang tuanya berpendidikan SMA, Ibunya sebagai pedagang. Orang tuanya memberikan pujian atas prestasi yang telah dicapai dan mengajarkan bekerjasama dalam keluarga, diberikan keleluasaan dalam menyelesaikan permasalahan yang dihadapinya. Dalam bekerja sesuai dengan tujuan dan kerangka waktu yang ditentukan serta target yang akan dicapai yaitu diajarkan tentang kedisiplinan dan kepemimpinan dalam keluarga.

Kemandirian dalam hidup juga dikembangkan dalam keluarga sehingga pada saat sekolah tidak lagi mengandalkan kiriman uang dari orang tua dan sudah terbiasa mengelola uang dengan baik yaitu perolehan dari usaha digunakan untuk berinvestasi di masa depan. Dalam membantu ibunya berdagang dilatih untuk menghormati orang lain dengan prinsip menempatkan orang lain sebagaimana layaknya seseorang yang pantas untuk dimuliakan.

Bapak Xa mempunyai motivasi berwirausaha dengan menambah pengetahuannya dengan membaca buku kewirausahaan, mengikuti seminar dan training entrepreneure serta praktik langsung dengan prinsipnya "learning, leading and serving". Dalam menjalankan bisnisnya ia mengevaluasi kelemahan dan kesalahan, dengan mengutamakan jaringan dan cutomer oriented.

Ibu $\mathrm{Lu}$ adalah seorang pengusaha di bidang Retail, beliau tinggal di Sleman. Pekerjaan ayah Ibu Lu adalah pegawai swasta, sedang Ibu sebagai Pedagang. Sejak kecil sudah dilibatkan dalam kegiatan Ibunya sebagai pedagang, untuk membantu Ibu berbelanja membeli bahan-bahan yang akan diperdagangkan yang tentunya dilakukan sepulang sekolah. Motivasi Ibu Lu adalah ikut membantu mengatasi persoalan ekonomi orang tua. Dalam hal ekonomi keluarga Ibu Lu berprinsip dan berusaha agar dalam bekerja tidak perlu banting tulang di pasar. Petuah orang tua yang dipegang adalah: "usaha keras agar dapat maju, jangan terburu-buru menuai hasilnya, gemi, atiati."Kerja keras merupakan modal menuju wirausaha yang sukses, wirausaha yang sukses selalu menempuh saat-saat ia harus bekerja keras membanting tulang dalam merintis usaha. Kerja keras ini tentu disertai disiplin dalam mengelola waktu sesuai dengan irama kehidupannya. Ibu Lu berprinsip bahwa jangan terburu-buru menuai hasilnya, gemi, ati-ati. Prinsip ini sesuai dengan teori kewirausahaan yang menjelaskan bahwa " Banyak wiraswasta yang mengalami kegagalan karena menganggap uang yang ada di tangan pada suatu saat adalah kekayaan yang dapat digunakan seketika itu juga. Wiraswasta tidak mau melihat cash flow perusahaan sampai akhir tahun depan minimal sampai kegiatan itu terselesaikan". Ibu Lu sudah 
memperhatikan cash flow dengan prinsip jangan terburu-buru menuai hasilnya, gemi, ati-ati

Bapak Dc adalah seorang pengusaha di bidang konveksi, beliau tinggal di Klaten. Orang tua beliau tinggal di Kalimantan. Pekerjaan ayah dan Ibu beliau adalah wirausaha. Sejak kecil, Bapak Dc memecahkan masalah dengan menekankan pada belajar untuk mandiri. Sewaktu masih tinggal di Kalimantan untuk ikut membantu pekerjaan baik di rumah maupun di kantor dan mengikuti kegiatan-kegiatan organisasi. Dari pernyataan Bapak Dc ini menunjukkan bahwa dalam keluarga beliau sejak kecil sudah ditanamkan untuk mandiri. Kemandirian merupakan hal yang sangat penting untuk menjadi wirausaha.

Ibu $\mathrm{Nu}$ adalah seorang pengusaha di bidang Retail dan cuci mobil, beliau tinggal di Perumnas Condongcatur Depok Sleman. Pekerjaan Ayah dan Ibu beliau adalah wiraswasta. Ibu $\mathrm{Nu}$ sangat terkesan dengan pujian utama yang diberikan oleh Ibunya adalah tatkala melaksanakan kegiatan yang berhubungan dengan berjualan. Sewaktu masih sekolah di SMP Ibu Nu merasa sangat berprestasi saat dapat menjual cumi-cumi kering di sekolahnya. Pujian yang diberikan oleh Ibunya ini menyebabkan untuk mengulangi lagi sehingga sampai dewasapun tetap berjualan. Waktu masih sekolah di SMP Ibu Nu harus bekerja keras, percaya diri dan disiplin yang tinggi. Dalam keuangan Ibu Nu berprinsip jangan sampai besar pasak daripada tiang, berarti beliau sudah mengatur keuangan dengan baik.

Sewaktu Bapak By masih kecil orang tuanya memberikan kebebasan namun Ibunya selalu mengontrolnya sementara Bapak yang memberikan banyak nasihat. Orang tuanya selalu mengajak diskusi tentang apa saja yang dirasakan oleh putranya terkait dengan belajar, teman-temannya, pilihan pekerjaan kelak dan sebagainya. Ayah selalu membimbing, memandu, mencarikan jalan keluar jika putranya mempunyai permasalahan yang dirasa berat. Orang tua Bapak By menerapkan kedisiplinan yang tinggi dalam hal sekolah. Kedisiplinan merupakan faktor yang sangat penting dalam kewirausahaan. Oleh karena Bapak By sudah terbiasa dididik untuk disiplin ternyata beliau sangat disiplin dalam kehidupannya sampai sekarang. Hal yang sangat terkesan waktu kecil adalah: Orang tua beliau tidak pernah mengatakan "jangan" terhadap pekerjaan atau kegiatan yang dilakukan anaknya tetapi memberikan gambaran, masukan, dan nasihat, tetapi keputusan tetap sepenuhnya diserahkan kepada Bapak By. Hal ini menunjukkan bahwa orang tua beliau memberikan kebebasan untuk mengambil risiko. Orang tua selalu memberi pujian atas prestasinya tetapi tidak pernah menghukum bila Bapak By melakukan kesalahan hanya diberi nasihat dan masukan agar tidak terjadi kesalahan yang sama. Penghargaan dari orang tuanya ini sangat bermakna bagi anak untuk meningkatkan motivasi berprestasi yang akan nampak dalam tindakan yang lebih baik dan lebih efisien dibanding sebelumnya. Sementara wirausaha yang sukses adalah wirausaha yang mempunyai motivasi berprestasi yang tinggi. Orang tua yang tidak memberi hukuman jika anaknya salah, tetapi memberikan masukan dan nasihat akan menjadikan anak tersebut merasa diberi peluang untuk melakukan kesalahan akibatnya anak tidak takut mengambil risiko, dan inilah yang merupakan kunci sukses dalam menjalankan usaha. Sebaliknya jika anak diberi hadiah jika berprestasi dan diberi hukuman jika melakukan kesalahan akan menjadikan anak takut salah dan akhirnya takut mengambil risiko. Orang tua Bapak By juga bukan orang tua yang otoriter yang ditunjukkan dengan kata "jangan" untuk melakukan kegiatan tertentu. Orang tua yang tidak otoriter akan menjadikan anaknya menjadi orang kreatif karena tidak pernah dilarang dengan kata lain tercipta lingkungan yang kondusif untuk berkreasi. 
Ibu Li adalah seorang pengusaha di bidang Retail, beliau tinggal di Kota Yogyakarta. Pekerjaan Ayah beliau adalah Guru, sedang Ibu sebagai pedagang. Sejak usia 12 tahun sudah mampu membuat/memproduksi dan menjual mainan bahkan pada usia 15 tahun sudah mengambil alih usaha orang tuanya untuk berjualan makanan kecil di sekolah, juga menjual pakaian ke rumah tetangganya. Jualan pakaian dilakukan setelah pulang sekolah. Orang tuanya sangat bersikap positif terhadap kegiatan ini karena dapat membantu ekonomi orang tua. Ibu Li ini merasa bertanggungjawab dan tidak malu (percaya diri) berjualan di sekolah karena statusnya sebagai anak pertama. Beliau sudah biasa bekerja keras karena disamping sekolah juga harus berjualan makanan ringan di sekolah dan berjualan pakaian sepulang sekolah ke tetangga-tetangganya, beliau juga disiplin dalam mengatur waktu antara belajar dengan berjualan. Bertanggung jawab, percaya diri, kerja keras, disiplin inilah barang kali yang menjadikan sukses berwirausaha saat ini, karena keempat hal ini memang merupakan bagian dari karakteristik wirausaha..

Bapak Ya berbisnis dalam bidang kuliner, tingkat pendidikan orang tuanya adalah tamat SMP. Ayahnya sebagai pedangang dan ibunya tidak bekerja. Dia anak pertama dari dua bersaudara laki-laki. Orang tuanya menerapkan pola pendidikan yang demokratis yakni sejak kesil sudah diberi keleluasaan dalam memilih sekolah. Orang tuanya juga memberikan pujian atas prestasi yang diperolehnya. Dia termasuk anak yang berprestasi diantaranya lulus dengan cumlaude, peraih medali emas PIMNAS dan juara III dalam Indocement Award dll.

Sewaktu SMK bekerjasama dengan temannya untuk menjual VCD/CD saat ini sebagai pelaku bisnis yang mapan dengan pengelolaan keuangannya sangat rapi yaitu perolehan keuntungan dialokasikan $1 / 3$ untuk operasional bisnis, $1 / 3$ ditabung dan 1/3 untuk pengembangan usahanya. Orang tuanya berkeinginan agar dia menjadi PNS, namun dia ingin menjadi pebisnis yang sukses dengan cita-cita sebagai owner suatu masakan dalam kemasan yang diproduksi secara massal,

\section{Peran Ibu dalam Menumbuhkan Jiwa Entrepreneurship Anak}

Pada awalnya Ibu Hy tidak ingin berwirausaha, karena Ibunya tidak menginginkan putrinya menjadi wirausaha dengan alasan khawatir kalau putrinya mengalami kegagalan.. Namun kenyataan setelah kuliah (kira-kira berusia 22 tahun) terjadilah perubahan besar pada diri Ibu Hy yang semula tidak ingin menjadi wirausaha karena tidak berani mengambil risiko menjadi sangat berani, namun beliau tidak bersedia memberikan penjelasan mengapa bisa berubah 180 derajat dari tidak berani mengambil risiko menjadi sangat berani, beliau hanya menyatakan bahwa: "orang yang berani mengambil risiko, ketika ada masalah akan siap menghadapinya". Meskipun beliau tidak memberikan alasan perubahan, tetapi dari yang tersirat menunjukkan perubahan itu terjadi karena teman dekatnya waktu itu, yang juga sebagai wirausaha. Berhubungan dengan masalah yang sering dihadapi Ibu Hy, beliau berprinsip setiap permasalahan pasti ada jalan keluar, Ibu Hy optimis dapat mengatasinya. Setelah Ibu Hy memperlihatkan hasil dari keberanian mengambil risiko maka orang tua khususnya Ibunya mendukung $100 \%$ kegiatan kewirausahaan yang dilakukan oleh Ibu Hy.

Bapak Xa merupakan anak pertama dan memiki adik laki-laki, orang tuanya berpendidikan SMA, Ibunya sebagai pedagang. Orang tuanya memberikan pujian atas prestasi yang telah dicapai dan mengajarkan bekerjasama dalam keluarga, diberikan keleluasaan dalam menyelesaikan permasalahan yang dihadapinya. Dalam bekerja sesuai dengan tujuan dan kerangka waktu yang ditentukan serta target yang akan dicapai yaitu diajarkan tentang kedisiplinan dan kepemimpinan dalam keluarga. 
Kemandirian dalam hidup juga dikembangkan dalam keluarga sehingga pada saat sekolah tidak lagi mengandalkan kiriman uang dari orang tua dan sudah terbiasa mengelola uang dengan baik yaitu perolehan dari usaha digunakan untuk berinvestasi di masa depan. Dalam membantu ibunya berdagang dilatih untuk menghormati orang lain dengan prinsip menempatkan orang lain sebagaimana layaknya seseorang yang pantas untuk dimuliakan.

Ibu Lu adalah seorang pengusaha di bidang Retail, beliau tinggal di Sleman. Pekerjaan ayah Ibu Lu adalah pegawai swasta, sedang Ibu sebagai Pedagang. Sejak kecil sudah dilibatkan dalam kegiatan Ibunya sebagai pedagang, untuk membantu Ibu berbelanja membeli bahan-bahan yang akan diperdagangkan yang tentunya dilakukan sepulang sekolah. Motivasi Ibu Li adalah ikut membantu mengatasi persoalan ekonomi orang tua. Dalam hal ekonomi keluarga Ibu Lu berprinsip dan berusaha agar dalam bekerja tidak perlu banting tulang di pasar. Petuah orang tua yang dipegang adalah: "usaha keras agar dapat maju, jangan terburu-buru menuai hasilnya, gemi, atiati."Kerja keras merupakan modal menuju wirausaha yang sukses, wirausaha yang sukses selalu menempuh saat-saat ia harus bekerja keras membanting tulang dalam merintis usaha keras ini tentu disertai disiplin dalam mengelola waktu sesuai dengan irama kehidupannya. Ibu Lu berprinsip bahwa jangan terburu-buru menuai hasilnya, gemi, ati-ati. Prinsip ini sesuai dengan teori kewirausahaan yang menjelaskan bahwa “ Banyak wirausaha yang mengalami kegagalan karena menganggap uang yang ada di tangan pada suatu saat adalah kekayaan yang dapat digunakan seketika itu juga. Wirausaha tidak mau melihat cash flow perusahaan sampai akhir tahun depan minimal sampai kegiatan itu terselesaikan". Ibu Lu sudah memperhatikan cash flow dengan prinsip jangan terburu-buru menuai hasilnya, gemi, ati-ati

Ibu dari Bapak Dc selalu memotivasi agar berani menghadapi masalah, karena beliau berprinsip setiap masalah pasti ada jalan keluarnya, jika belum menemukan jalan keluar maka "Tanyalah pada orang yang tahu dan mau memberitahu"kata ibunya. Kata-kata ibunya inilah yang selalu ia pegang. Orang tuanya menyarankan pada putranya untuk berkomunikasi dengan orang-orang yang kompeten di bidangnya ditambah untuk banyak membaca buku karena dari sinilah beliau beranggapan akan menemukan ide untuk memecahkan masalah.

Ibu $\mathrm{Nu}$ adalah seorang pengusaha di bidang Retail dan cuci mobil, beliau tinggal di Perumnas Condongcatur Depok Sleman. Pekerjaan Ayah dan Ibu beliau adalah wiraswasta. Ibu $\mathrm{Nu}$ sangat terkesan dengan pujian utama yang diberikan oleh Ibunya adalah tatkala melaksanakan kegiatan yang berhubungan dengan berjualan. Sewaktu masih sekolah di SMP Ibu Nu merasa sangat berprestasi saat dapat menjual cumi-cumi kering di sekolahnya. Pujian yang diberikan oleh Ibunya ini menyebabkan untuk mengulangi lagi sehingga sampai dewasapun tetap berjualan. Waktu masih sekolah di SMP Ibu Nu harus bekerja keras, percaya diri dan disiplin yang tinggi. Dalam keuangan Ibu Nu berprinsip jangan sampai besar pasak daripada tiang, berarti beliau sudah mengatur keuangan dengan baik.

Bapak By mempunyai Ibu yang berwirausaha di bidang perdagangan yang selalu melibatkan Bapak By dalam menjalankan usahanya bahkan sejak di bangku SD dilibatkan secara sukarela dalam berdagang untuk membantu kulakan, menunggu warung, dan disuruh pesan barang. Sewaktu Bapak By kecil, Ibu beliau sering mengajak untuk menonton seni tradisional, dari sinilah mungkin beliau merasakan perlunya ada usaha di bidang event organizer dan kuliner.

Sejak berusia 15 tahun Ibu Li sudah mengambil alih usaha orang tuanya untuk berjualan makanan kecil di sekolah, juga menjual pakaian kepada tetangganya secara kredit. Jualan pakaian dilakukan setelah pulang sekolah. Hal ini hanya dapat 
dilakukan oleh anak yang percaya dirinya tinggi, kerja keras dan disiplin mengatur waktu. Orang tuanya sangat bersikap positif terhadap kegiatan ini karena dapat membantu ekonomi orang tua. Oleh karena Ibu Li sejak kecil sudah mengambil alih usaha ibunya, dengan demikian sudah biasa menjadi wirausaha.

Bapak Ya berbisnis dalam bidang kuliner, tingkat pendidikan orang tuanya adalah tamat SMP. Ayahnya sebagai pedangang dan ibunya tidak bekerja. Dia anak pertama dari dua bersaudara laki-laki. Orang tuanya menerapkan pola pendidikan yang demokratis yakni sejak kesil sudah diberi keleluasaan dalam memilih sekolah. Orang tuanya juga memberikan pujian atas prestasi yang diperolehnya. Dia termasuk anak yang berprestasi diantaranya lulus dengan cumlaude, peraih medali emas PIMNAS dan juara III dalam Indocement Award dll.

Sewaktu SMK bekerjasama dengan temannya untuk menjual VCD/CD saat ini sebagai pelaku bisnis yang mapan dengan pengelolaan keuangannya sangat rapi yaitu perolehan keuntungan dialokasikan 1/3 untuk operasional bisnis, 1/3 ditabung dan 1/3 untuk pengembangan usahanya. Orang tuanya berkeinginan agar dia menjadi PNS, namun dia ingin menjadi pebisnis yang sukses dengan cita-cita sebagai owner suatu masakan dalam kemasan yang diproduksi secara massal,

\section{Faktor-faktor yang Dominan untuk Berkembangnya Jiwa Entrepreneurship Anak.}

Dari beberapa kasus yang dijadikan subjek penelitian, Kasus Bapak Xa (Ibu beliau pedagang), Kasus Ibu Lu (Ibunya sebagai pedagang) Kasus Bapak Dc (kedua orang tuanya wirausaha), Kasus Ibu Nu (Ibu beliau Wirausaha), Kasus Bapak By, (Ibu beliau adalah wirausaha) dan kasus Bapak Ya bapaknya pedagang) menunjukkan pelaku usaha yang berhasil banyak dipengaruhi oleh faktor lingkungan. Hanya sebagian kecil 1/8 (12,5\%) yang dipengaruhi oleh faktor dari diri sendiri (Ibu Hy), responden ini menyatakan bahwa pada awal mulai berusaha karena memiliki keinginan berprestasi yang sangat tinggi. Kasus Ibu Hy, orang tua tidak menginginkan putranya menjadi wirausaha, tetapi setelah berwirausaha ternyata sukses dan orang tuanya mendukung kegiatan berwirausaha ini, Ibu Hy merasa tidak takut mengambil risiko, dan selalu menghadapi tantangan dengan prinsip jika ada kemauan di situ ada jalan.

Faktor personal environmental yaitu pengaruh dari luar. Sebagian reponden sukses berwirausaha karena orang tuanya sudah melibatkan untuk menjadi wirausaha, contohnya banyak yang orang tuanya menjadi wirausaha maka putranya menjadi wirausaha. Beberapa responden menunjukkan bahwa orang tuanya adalah wirausaha dan beliau juga sukses di bidang wirausaha (kasus Bapak Xa, Bapak By, Bapak Dc, Ibu Li, Ibu Lu, Ibu Nudan Bapak Ya). Sejak kecil sudah dilibatkan dalam kegiatan ayah atau ibunya sebagai pedagang, untuk membantu Ibu berbelanja membeli bahanbahan yang akan diperdagangkan yang tentunya dilakukan sepulang sekolah.. Hanya Ibu Hy yang orang tuanya pegawai negeri tetapi beliau sebagai wirausaha yang sukses

\section{Keterbatasan Penelitian}

Teknik pengumpulan data dalam penelitian adalah wawancara mendalam kepada Ayah-Ibu dari pelaku usaha, beserta keluarga, namun karena berbagai alasan maka teknik ini tidak dapat dilaksanakan akan tetapi data diambil dari persepsi pelaku usaha tersebut mengalami, merasakan dan terkesan dengan pendidikan yang diterimanya dari ibunya, alasan tersebut antara lain:

1. Ibu dari Wirausahawan/pelaku usaha tidak tinggal bersama sehingga secara teknis sukar melaksanakan wawancara. 
2. Ibu dari Wirausahawan/pelaku usaha sudah meninggal dunia.

\section{Penutup}

\section{Kesimpulan}

a. Peran pendidikan dalam keluarga dapat menumbuhkan jiwa entrepreneurship anak. Secara umum pendidikan dalam keluarga berperan dalam menumbuhkan jiwa wirausaha anak. Wirausaha yang sukses pada umumnya dipicu dengan pendidikan yang demokratis, dilatih kemandirian, kepercayaan diri, kerja sama, kerja keras, disiplin, serta menghargai orang lain

b. Kebanyakan $(75 \%)$ ibu berperan dalam menumbuhkan jiwa wirausaha pada anak, ajakan Ibu untuk melibatkan anak dalam kegiatan kewirausahaan menjadikan anak untuk mempertimbangkan wirausaha sebagai pilihan karirnya

c. Faktor-faktor yang dominan untuk berkembangnya jiwa wirausaha adalah lingkungan. Faktor personal environmental yaitu pengaruh dari luar. Sebagian reponden $(87,5 \%)$ yang sukses berwirausaha karena orang tuanya berkecimpung di bidang kewirausahaan.

\section{Saran}

a. Sebaiknya orang tua menerapkan pola didik demokratis dan memberikan gambaran tentang berbagai jenis lapangan pekerjaan kepada anak.. Orang tua perlu mengubah pola berfikir bahwa pada kondisi saat ini anak perlu diarahkan untuk menciptakan kerja bukan hanya mencari kerja, karena adanya kesenjangan antara tersedianya peluang kerja dengan jumlah pencari kerja.

b. Ibu perlu melibatkan aktivitas kewirausahaan (kemandirian, disiplin, percaya diri dll) kepada anak karena ibu lebih dekat dengan putranya di masa kanak-kanak

\section{DAFTAR PUSTAKA}

Buchori Alma. (2005). Kewirausahaan. Bandung: Alfabeta

Meredith G. Geofrey.(1996) Kewirausahaan Teori dan Praktik, Jakarta: Pustaka Binaman Presindo

Nana Syaodih Sukmadinata (2009). Metode Penelitian Pendidikan. Bandung: PT Remaja Rosdakarya

Scarborough, Nurman M. Thomas W. Zimmerer. (1993) Efective Small Bussiness Management. New York: Mac. Millan Publishing Comp

Slameto. (2003). Belajar dan Faktor-Faktor yang Mempengaruhinya. Jakarta: Rineka Cipta

Sugiyono. ((2010). Penelitian Pendidikan Pendekatan Kuantitatif, Kualitatif dan R\&D) Bandung: Alfabeta

Suryana. (2003) Kewirausahaan Pedoman Praktis, Kiat dan Proses Menuju Sukses. Jakarta: Salemba Empat 